deserved dizrepute and consequent neglect of one of the most generally useful drugs in the Pharmacopaia.

Bismuth.- In the treatment of gastritis, whenever there is evidence of much irritution by pain, furred tongue, icterus, or mucous vomiting, etc., bismuth is indicated. It may be given in various combinations and forms: for example, in subacute gastritis I give with blue pill and a saline aperient the following powder, to be taken thrice daily before food: H. Bismuth. salicyl., gr. $x$; sodii bicarb., gr. $x$; pulv. rhei, gr. iij; pulv. cinnamomi co., gr. v. l't. pulv. Mitte xij. It should be taken in milk, and is an excellent remedy for ordinary use. Where the bowels are irritable l omit the rhubarb. In chronic gastritis, with mucous vomiting, I give the following: li Bismuthi carb., gr. $x v$; sodii bicarb., gr. $x$; muc. tragacanthi, 3 ss. ; aq. ad $\xi j$; M. ft. ht. Sig. To be taken thrice daily before meals. In cases of atony, with slight gastritis, I order: $\mathrm{k}$ Liq. bismuthi et ammon. cit., $3 \mathrm{j}$ : sodii bicarb., gr. $x$; tr. nucis vom., $m x$; inf. gentiana ad 3j. M. ft. ht. Sig. To be taken thrice daily before meals.

Hydrochloric Acid and Pepsin.-We have seen that not very uncommonly there is distinct deficiency in the hydrochloric acid of the gastric juice; it is difficult to give as much as is needed to compensate for defective secretion, but fifteen drops in a wineglassful of water may be taken through a tube every hour for four hours after each meal. Pepsin is much more rarely absent, as so little of the ferment is actually necessary, but when artificial digestion has determined the want of it, it may be very easily supplied by any of the good preparations now in the market. In connection with the use of these remedies, it may be said that they do not do so much good as might be expected, nor does their absence produce the ill-effects we should anticipate. In fact, so long as the food is not retained too long in the stomach its chemical condition is of comparatively little importance, the deficient digestion in the stomach being made up by the activity of the pancreatic and intestinal juices. It is therefore to the various means for promoting motor activity that we should chiefly look in the treatment of these cases.

\section{REMARKS ON AMGBIC ABSCESS OF THE LIVER.}

By PATRICK MANSON, M.D., LL.D., Physician to the Seamen's Hospital.

WITH A REPORT ON THE PATHOLOGY

By JAMES GALLOWAY, M.D., F.R.C.S., M.R.C.P., Pathologist to the Great Northern Central Hospital.

Is common with many other observers I have frequently, since Kartulis brought the subject prominently before the profession, found amœbæ in dysenteric stools. But, although I had searched more than once for similar parasites in the discharge of liver abscess, I had hitherto failed to discover their presence in this medium until I came across the following case. So far as $I$ am aware, this is the first time the amoba has been found in liver pus in England; at all events, no similar case has been published in any English journal, although a good many are now on record in American and German, and $a$ few in French and Indian publications. The value of the case is very much enhanced by Dr. Galloway's report on the microscopical examination of the liver tissue ; to a certain extent this is confirmatory of Councilman and Lafleur's important researches.

\section{History of the Case.}

M. T., aged 30, fireman ss. Carthage, was admitted to the Albert Dock branch of the Seamen's Hospital, Green wich, on September 4th, 1893. He stated that he was a native of Zanzibar, that for many years hie had resided in Jeddah, Arabia, and that latterly he had been employed as a fireman on steamers running between Bombay and London. stated that he had been healthy, and hod not suffered from diarrloea or stated that he had been healthy, and had not suffered from diarrloea or
dysentery. He had been ill since the arrival of his ship in the London dysentery . He had been ill since the arrival of his ship in the London Docks-a fortnight before his admission-and for two or three days pre-
viously, while at sea, with pain in the belly, a feeling of fulness after eating, occasional vomiting and feverishness, his symptoms being at eatvated by any attempt to work. I did not see him till September 18 th. I then found him complaining of the symptoms mentioned, and, in addition, I could make out by palpation an ill-defined swelling in the epigastrium. The swelling was smooth, rounded, slightly tender, about the size of two fists, and apparently connected with the liver. This organ was slightly sensitive on perrussion in iront, and it measured rather over inches in the nipple line. I spot below and to the left of the xiphoid cartilage was distinctly tencler. At this point particularly but

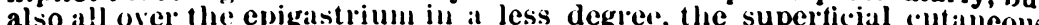

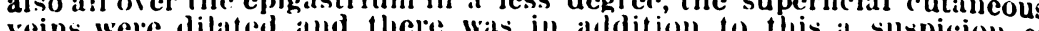
redemit. The urine contained at trate of allbunen, but wats of fair specific

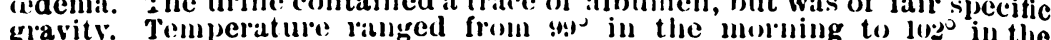
evening. Sweating had occurred only once or twice, and was not a evening. Sweating
marked svmptom. marked symptom.
suspetting abscess of the liver, and with a view to clearing up the
diagnosis, and, if pus were discovered, to operating, on September voth the patient was put under chloroform. When lie was deeply anaesthetised the swelling in the epigatstrium could be readily made out; but it was now discovered for the first time that on light pereussion over the tumour a distinct tympanitic note could be elicited. In the absence of any history of expectoration. vomiting, or passing of pus by stool, it was coun.luded that this tympinitic resonance was owing to gut or stomach intervening between liver and the abdominal wall; and it was deemed prudent to defer exploration for a day or two to give time for fresh developments to occur and for preparation for irliat might prove to be an extensive laparotoms. I week later, no improvement laving taken an extensive laparotoms place, a thpoderde line, and pus witldrawn. Next day this proceeding right of the midde one, and pus withdrawn. Next day this procecding was repeated, and on subjecting the chocolate-coloured pus to micro-
scopical examination it was found to contain many actively moving amobae. On October 4 th, the tympanitic resonance in front of the tumour still persisting, an incision about 3 inches in length was made in the epigastrium to the right of the middle line, and the dissection carefully carried into the peritoneal cavity. No adhesions were apparent, but a knuckle of small intestine showed itself at the wound, suggesting an ex. planation for the tympanitic resonance referred to. The gut was easily pushed aside. A hypodermic needle passed into the liver in an upuards in wards, and backwards direction, entered an abscess cavity. On pass:

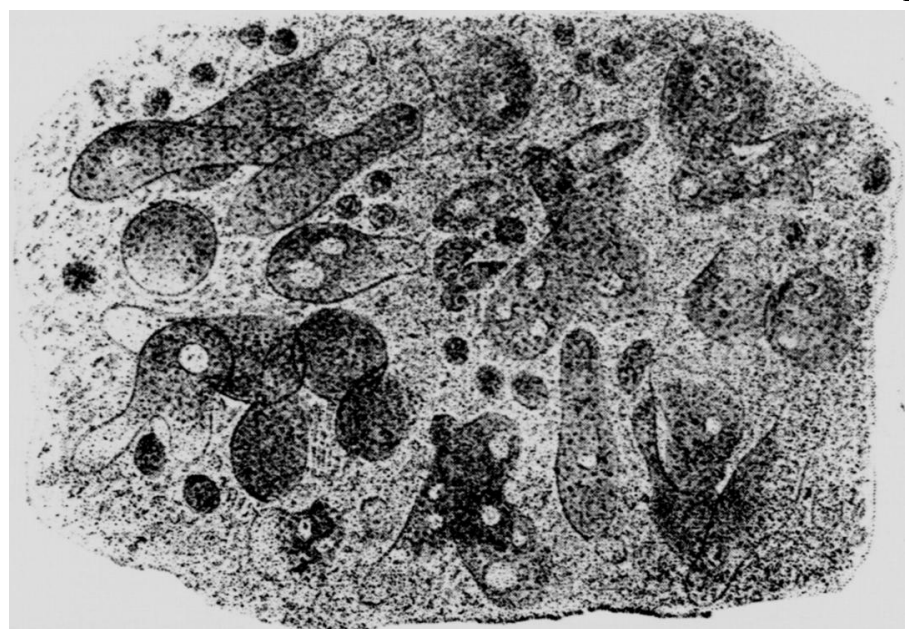

Amclba coli in intestinal mucus, with blood corpuscles, schizomycetes, and similar bodies (after Lösch).

ing a finger into the wound, extensive and firm adhesions were dis covered to the left of the middle line. The original wound was therefore stitched up and a fresh incision made through the abdominal wall in the situation of the adhesions. Thade through the abdominal wall in a small orange at a short distance from the surfaces about the size of was felt to be rough, irregular, and moderately resistant. The contents was felt to be rough, irregular, and moderately resistant. The contents coloured, with here and there streaks of almost pure blood and yellow mucoid pus, the whole assuming an almost jelly-like consistence on cooling. Four hours later, on placing some of this pus under the microscope, living amobre were found in it in abundance-sometimes as many as six or seven in one field of a onc-inch objective. The patient did not rally from the operation-which was a simple enough affair and skilfully performed by Mr. Jolnnson Smith-but died about 48 hours afterwards. No post-mortem examination could be obtained; such examination as could be made through the wounds be obtained; such exadetect any sign of hamorrhage or leakage of pus into the peritoneal detect any sign of hamorrhage or leakage of pus into the peritoneal placed in spirit and handed to Dr. James Galloway for microscopical examination. To him I am indebted for the following report.

\section{Dr. Galloway's Report.}

[From the Laboratories of the Royal Colleges of Physicians and Surgeons.]

The tissues handed to me for examination consisted of portions of liver, including part of the anterior edge. To consisted of portions of pieces resembled liver substance apparenty little ared eye some of the sisted of very dense fibrous tissue apparenty little changed, others concliange in the liver structure. The last were of portions showed great change in the liver structure. The last were of a dark brown colour, of exceedingly fragile consistence, and they gradually passed into normal liver substance at the margins of what weere evidently cavities produced by necrosis. Pieces from each of these types of material were placed in absolute alcohol, then, after being embedded in paraffin, were cut in sections and submitted to microscopic examination. The stains made use of to bring out the characteristies of the tissue were hiematoxylin Ehrlich), hamatoxylin and cosin, and methylene blue.

1. The liver tissue, through considerable areas, shows the hepatic cells unaltered. The most striking change is a considerable increase of connective tissue along the course of the culation. Thus the liver has some re main branches of the portal cir- 
as "coarse ritrhosis," but it differs from this on account of the exceedingly artive appeatatuce oi the tibrous tissue, and also becallse the tibrous tissue is less alitlusely distributed than in the lesion mentioned. In the? bands of newly-formed commertive tisstle: were observed very llumerous bile ducts, especially neal the margins of lobules, encroateined on hy the developing connective tissue cells. The number of these bile ducts. developly of new formation, is mueh greater than is seen in cases of probably cirliosis, and greater even than is observed in ciscs of the hypercoarse or biliary cirriliosis.

trophic or biliatry.

2. The fibrous tissue, found in areas apart from necrosing liver tissue, is well developed, very dense, and sllgigests the fact that it miny have been formed on the site of older lesions thith those which immediately preceded deatle, and it is probibl)ly in relition to these masses of sear throughout the fibrous tissue are numerou; rells of irregular, but usually somewhat elongated, shape, o(c)asionally arranged in rows or usuans, and almost inviriably containing yuantitie; of brownish pig ment particles. These are, no doubt, relie's of the secreting cells of the liver which have undergone degeneration.

3. The areas of recent lesion, however, show the most interesting changes. As already remarked, these are of a dark biown colour, exchadingly brittle, almost melting away in water, and require careful embedding to secure proper sections.

bedding to secure proper sectively normal liver tissue passes almost inThe surrounding (comparatively normal liver tissue passes almost insensibly into the brown mass mentioned. There is no boundary of fibrous tissue, and it is very striking to observe the remarkable absence of leucocytic infiltration round the margins of such areas. The hepatic brown matrix. In the latter no formed elements are to be seen, with the exception to be noted, but it consists of granular material, in which may be observed, especially towards the normal liver substince, small particles of chromatin persisting from the nuclei of cells which have undergone degeneration. There may be observed, however, in certain spots numerous cells, usually rounded in outline, from 0.016 to 0.021 millimetre in diameter, and presenting a licalthy well-developed appearance. The nucleus is not very distinct, but is invariably present, and there are usually to be seen one or two pigment particles in the surthere are usually to be seen one or two pigment particles in the surrounding plotoplasm. The presence of vacuoles cannot be well ascertained. To all appearance these structures resemble the bodies described by "1.s. Councilman and Lafleur in their description of "Amcebic hyse been carried into the liver. They are certainly somewhat anomalous in character, and differ from the ordinary form of degeneration of liver cells. The latter are met with in large numbers, and are shrunken, usually elongated, bodies containing a large quantity of pigment. On the other hand, the structures under discussion are rounded well-defined cells in which there is little appearance of degeneration, and it is a striking fact that they remain apparently healthy in the midst of obviously necrosed tissue.

The amobae of dysentery have so rarely been searched for in this country that I have some difficulty in deciding whether these bodies are really the micro-parasites as deseribed by Councilman and Lafleur, or whether they may not be the result of some form of degeneration of whercels, which causes the nuclein and cell protoplasm to become liver cels, which causes the nuclein and cell protoplasm to become which is readily recognisable.

It is very notewortly in this respect that in the series of cases examined by $\mathrm{Dr}^{\circ}$. Albert Calmette, in Cochin China, he has not been able to identify the amoba of Kartulis in a single case of liver abscess. This observation is worthy to bu borne in mind in considering the subject, for it is not likely that the bodies seen so readily in these preparations, and said to be discovered with ease by Councilman and Lafleur, can have been overlooked by so careful an observer as Calmette.

On the other hand, the fact may empliasise the conclusion that there is more than one class of liver abscess in dysentery, one being possibly the result of absorption from the colon of toxins which have a polective the result of absorption from the colon of toxins which have a selective possibly associated with the amceba coli as a cause (Kartulis, Councilman, Lafleur, etc.).

The occurrence in this case of tympanitic resonance on light percussion over a liver abscess which did not communicate with either lung or alimentary canal, and the probable explanation of this unusual circumstance discovered at the time of operation, is of considerable clinical interest. My object, however, in recording this case is to call attention to the association of amoeba coli with liver abscess, an association which, although it seems to carry with it distinct prospects of a great advance in the pathology of an important section of tropical disease, and which, thorefore, should be of special interest to Englishmen, yet nevertheless has hitherto been better appreciated in America and on the Continent than either in England or in India. In this neglect by our countrymen we have but a repetition of the history of a similar and even more important discovery - that of Laveran's plasmodia -in another department of tropical pathology.

In view of recent discovery it is manifest that the old views of the etiology of liver abscess must be abandoned. So long as the amoba coli seemed to be confined to the intestinal discharges, more particularly as it, or a species resembling it, was frequently found in simple diarrhœea, and even in healthy stools both in men and animals, and that often apart from any recognisable morbid condition whatever, so long it

1 Councilman and Lafleur, .Johns IIopkins IIospitul Reports, 1891.

2 Calmette, Archives de Médecine Navale et C'oloniale, 1893. sermed to have little claim to be regarded as an important pathological factor. But since Kartulis in Eigypt. Osler, Councilman and lafleur and others in America, llehir in India, and others have shown that it may be present in the contents and even the wall of liver alsserss, it has acquired an additional and weighty claim to be regarded as probably something more than a fortuitous epiphenomenon in certain diseases. That we have in amceba coli the explanation of all or of any of the forms of liver abseress 1 do not go the length of asserting; but its frecpuent presence in liver abscess, taken in conjunction with certain other cireumstances, must, I think, to say the least, be looked on as extremely signiticant and calling for extended investigation.

Calmette's suggestion, that the necrosis of the liver tissue resulting in tropical and dysenteric liver abscess is produced by the disintegrating action of toxins absorbed from the surface of dysenteric ulcers, is ingenious; but this view takes no account of the many cases of abscess the formation of which precedes the dysenteric ulceration it may subsequently become associated with, nor of those cases in which dysentery is at no time a feature. It seems to me probable that the immediate cause is the same in every instance. It would be strange if this form of disease, with a geographical distribution so peculiarly limited, should be brought about by a variety of causes, each of which must concur in possessing a similarly limited geographical distribution. It might be asked of a supporter of the amcebic doctrine of liver abscess : Why-assuming that the amceba is the cause-is this parasite not found in every instance? A possible answer to this would be, that the amoba may really be present in every instance at one time or another, but that, like the micro-organism of malaria, it may be polymorphic in character, and that we do not as yet know or recognise all its phases.

Regarded as an abscess, liver abscess is peculiar in many ways. First, in a large proportion of cases, the contents are not pus in the proper sense of that word; they consist principally of blood, detritus of liver tissue, a mucoid material, and usually only a very small proportion of pus proper. Secondly, in liver abscess there is no well-defined abscess wall or extensive infiltration of leucocytes into the surrounding and still living tissues in the earlier stages, nor, in many case's, at any stage ; a circumstance which suggests that whatever may have been the cause of the breakdown of the tissues, this cause differed in its mode of action from ordinary pyogenic bacteria, inasmuch that it gave rise to very little, if any, tissue reaction. In fact, liver abscess seems to be more a necrosis than a suppuration.

Thirdly, in a large proportion of cases, the usual pus bacteria are entirely absent. In many instances in which cultivations of liver abscess pus have been attempted the tubes have remained sterile. This fact has been thoronghly made out by several reliable bacteriologists. The latest observations and experiments of this description with which I am acquainted are those alluded to by Dr. Galloway, namely, Calmette's. He found the pus of seven liver abscesses absolutely sterile: and free from bacteria. There are now a good many similar observations on record, so that it may be considered as cstab. lished that usually tropical and dysenteric liver abscesses arc sterile as regards the ordinary pyogenic bacteria.

Are we not justified in regarding the peculiar structure and contents, the absence of pyogenic bacteria, and, in many instances, the presence of amcebs, not only in the contents but in the walls of liver abscess, as being in all probability correlated circumstances? Do not these circumstances suggest that the amœbre are the cause of those abscesses in which they occur, and of their distinctive peculiarities; that, preying on the liver tissues, they break these down piecemeal and so create the peculiar and characteristic purilage? The frequent and well-known association of liver abscess with dysentery, and of dysentery with amœbæ gives further sup port to this view.

Up to the present, the data in our possession are insufficient to warrant definite conclusions, but the facts I have mentioned point distinctly to the probability that the amoba is at the bottom of the pathology of many cases of liver abscess. At all events, they are sufficiently striking to make it tho duty of pathologists to follow the matter up, and of the practitioner to provide the pathologist with material and carefully observed clinical facts. Whenever a liver abscess is opened 
or explored the contents ought to be examined for amcolse, and also submitted to cultivation experiment for the detection of other micro-organisms.

This latter may not be always possible for the practitioner to carry through, but it is always an easy matter for him to ascertain the presence or absence of amoba. Such an examination is a very simple matter, and requires little skill or special apparatus. A little of the abscess contents is placed on a slide and spread out in a thin layer by pressing on the cover glass. It is then examined with a magnifying power of from 80 to 100 diameters. If amoba are present, they are readily recognised as clear, splierical globules, about three or four times the diameter of blood corpuscles, and lying isolated among the blood, pus, and liver detritus. Several fields may have to be scrutinised before they can be found or their absence pronounced on. Under a power of 250 to 300 diameters, on placing the slide on a warm stage, the amœboid nature of these bodies is readily detected. It is well to select for special examination an amoba lying in any islet of clear serum which may be present in the preparation; here the movements are easily made out. In this climate, to elicit the amcboid movement a warm stage is necessary ; this fact may be an obstacle to some who would otherwise be willing to make the necessary examination; but a very simple apparatus is all that is necessary. For my examinations I have used a long piece of tin with a hole cut in one end for the transmission of light, a spirit lamp being applied to the other end. No delicate regulation of temperature is necessary. In hot climates a warm stage is not required. As the temperature of the slide approaches $100^{\circ} \mathrm{F}$. the amœbæ become very active-not all of them, but most of them. When the temperature falls below $80^{\circ} \mathrm{F}$., they become globular and passive, or exhibit only very languid movements. If it be inconvenient to examine the abscess contents in the patient's house, it will suffer nothing by a five or six hours' delay, and may therefore be taken home by the observer and examined at leisure.

The illustration on page 676 conveys a very good idea of the amoba and of its size relative to that of the blood corpuscles usually present in slides of liver pus and dysenteric dejecta, and which, therefore, form a convenient standard of measurmeent. The clear rim of ectosarc which tips the advancing pseudopodium in several of the amcbæ is very characteristic and is well represented. The only points in the figure I would take exception to are the vacuoles which in Lösch's drawing are too pronounced, and the very large number of amœbæ in the limited field-1 have never seen them thus crowded together. Perhaps, too, the endosarc is somewhat too deeply shaded. Otherwise the figures conveys a graphic conception of the various shapes the amœba assumes in its movements.

\section{IS DYSENTERY THE INVARIABLE PRECURSOR OF “ TROPICAL" LIVER ABSCESS ?}

\section{BY NEIL MACLEOD, M.D.EDIN., Shanghai.}

During the first years of my acquaintance with liver abscess, its relationship with dysentery seemed to me only occasional. This conclusion was based partly on the literature of the subject and partly on clinical observation, from which alone the answer to the above query would certainly not be in the affirmative. For some years past $I$ have been convinced that the answer to the question should be practically in the affirmative, and that the facts urged against this view -namely, the absence, in certain cases, of a history of bowel disturbance or of ulceration of the large intestine on postmortem examination-have another interpretation. Two recent fatal cases in my practice furnish striking illustration of some of the points connected with this question. It is very generally accepted that multiple liver abscess-portal pyæmia as it is sometimes designated-is secondary to dysentery, but if single hepatic abscess is not to be attributed to the same cause, owing to the absence of antecedent dysenteric history, such causation ought likewise to be denied to multiplo abscess, as may be seen from the following case:
A robust well-preserved man of 52 felt slightly ill on October e2nd, and took to bed on the following day. Iiver dulness was not appreciably increased on the 24th, slightly increased on the 26 th, distinctly so on the 28th, with slight jaundice. Uneasiness in the right side and epigastric tenderness were felt, and the hepatic dulness increased thereafter till it extended from the nipple to the umbilicus. On November end friction could be felt and heard over the lower ribs laterally, and on the following day in the epigastrium. The jaundice deepened daily, and on ing day in the epigastrium. The jaundice deepened daily, and on November 5 th a tumblerful of pus was evacuated from an opening made
in the right epigastrium. The sliock was out of all proportion to the in the right epigastrium. The sliock was out of all proportion to the severity or duration of the operation, and death took place in forty-eight hours. There was no history of bowel disturbance before the illness set in as described, but in its course the stools were soft. and, aiter a purga-
tive, a small quantity of mucus, on one occasion reddish, was observed. tive, a small quantity of mucus, on one occasion reddish, was observed.
Post-mortem examination revealed ten abscesses of right and left liverlobes, all larger than a small orange. Between twenty and thirty ulcers, from a-quarter to a whole inch in diameter, were present in the caecum.

This patient, a man occupying a prominent position, one of the busiest men in the East, was going about neither feeling ill nor suspecting that there was anything wrong with the bowel, hard at work up to the first day of his illness. That dysenteric ulceration occurs without attracting the patient's attention is evidenced by the occurrence of hæmorrhage. from the bowel, where no piles, typhoid, or tuberculous ulceration are present, the hæmorrhage being the first thing that attracts notice, and subsequently proofs of dysenteric disturbance are obtained. In a case of the kind noteworthy for its termination-to which Dr. Milles, of Shanghai, allows. me to refer-he opened a single hepatic abscess, and death followed in forty-eight hours from bowel hæmorrhage. Postmortem examination revealed ulceration of the large gut and the ruptured vessel. This case had no history of bowel disturbance, and, but for the hæmorrhage and post-mortent examination, would have gone to swell the number of single hepatic abscesses not preceded by dysentery. That degrees of dysentery may exist, from the most severe and fatal process to one not apparently interfering with health, is only in keeping with what is known of nearly every other disease that comes under observation.

Yet another class of cases is met with. Ten years ago a man from Pekin came under observation from fever, which was suspected and demonstrated after the lapse of a few weeks to be symptomatic of suppurative hepatitis, and that multiple. There was no history of diarrhœea or dysentery, and post-mortem examination of the large gut furnished traces of ulcers in the shape of unpuckered cicatrices. The following case aftords absolute proof that the dysenteric process with ulcers may exist prior to the occurrence of hepatic abscess, and that the ulcers may heal before death.

On August 24th commenced a typical attack of dysentery in a man of 26 . The stools having lost their dysenteric character, but occasionally containing blood, and there being no piles, on September 19th he was sent. north to Chefoo, to escape the Shanghai heat. with a note to a physician north to Chefoo, to escape the Shanghai heat. with a note to a physician there stating that the thermometer gave no evidence of fever, and that there was no sign or symptom of liver disturbance at the latter date. At. Chefoo fresh dysenteric trouble manifested itself, and was followed by $28 \mathrm{th}$. Aspiration of the liver ailed to reach pus on October $2 \mathrm{nd}$, and at sea on the 13th symptoms of rupture into the peritoneum either of an abscess or of an ulcer of the descending colon were followed by peritonitis. Evacuation of 12 ounces of pus from the liver gave no relief. and death occurred on the 24th, two days after the operation. Examination after death showed a single abscess of the back part of the right. lobe of the liver. This abscess had ruptured below, and communicated with an encysted collection of about 6 ounces of pus lying below the left lobe. From this on the extreme left leakage had taken place, causing almost general peritonitis. The colon presented no ulcers, but there. almost general perito

The ulcers in the colon in this case must have healed subsequent to September 19th, and probably while the hepatitis was going on, since (1) the absence of a history of diarrhœa or dysentery in a case of liver abscess does not negative ulceration of the large gut; (2) in every fatal instance of liver abscess that I have examined after death, some 20 or 30 ulcers or their cicatrices have been found; $(3)$ in the majority of those cases of hepatic abscess that I have seen recover, symptoms of dysentery have preceded the inflammation; (4) "tropical" liver abscess seldom or never occurs except in those who are or have been resident in countries where dysentery prevails; and since (5) an ulcer of the large bowel overlying a vein with an opening in the latter (and this occurs in dysentery occasionally) furnishes conditions which can set up suppurative hepatitis, single or multiple.

I hold that the answer to the heading of this paper should be tropical liver abscess (and by this is meant cases in which the suppurative process is not a part of a general pjæmia, 